\title{
Enzymatic Hydrolysis and Fermentation of Plantain Peels: Optimization and Kinetic Studies
}

\author{
Philomena Kanwulia Igbokwe, Christian Nnabuike Idogwu, Joseph Tagbo Nwabanne \\ Department of Chemical Engineering, Nnamdi Azikiwe University, Awka, Nigeria \\ Email: chrisnna4life@yahoo.com
}

Received 31 December 2015; accepted 25 April 2016; published 28 April 2016

Copyright @ 2016 by authors and Scientific Research Publishing Inc.

This work is licensed under the Creative Commons Attribution International License (CC BY).

http://creativecommons.org/licenses/by/4.0/

(c) () Open Access

\section{Abstract}

The aim of this work was to optimize the hydrolysis and fermentation of plantain peels. Kinetic study was also carried out. Proximate analysis of plantain peels was carried out and the result showed that it contains $46 \%$ cellulose. Aspergillus niger isolated and screened for cellulase activities was used as the crude enzyme for the hydrolysis and commercial available Saccharomyces cerevisae was used for the fermentation. The optimization was done using quadratic model of central composite rotatable design for both hydrolysis and fermentation. Analysis of variance ANOVA was used to test for the significance of the model and the factors. The results of the analysis showed that temperature, time, $\mathrm{pH}$ and the substrate concentration significantly affected the yield of simple sugar in the hydrolysis of plantain peels. The result equally showed that temperature, time and $\mathrm{pH}$ were significant factors of fermentation. The optimum conditions for the hydrolysis were $35^{\circ} \mathrm{C}$, 5 days, and $\mathrm{pH}$ of 5.5 , substrate concentration of $8 \mathrm{~g} / 30 \mathrm{ml}$ and glucose yield of $49 \%$. Also the optimum conditions of fermentation were obtained as $30^{\circ} \mathrm{C}, \mathrm{pH}$ of $4.0,9$ days and ethanol yield of 19\%. The Michaelis-Menten model adequately fit both the hydrolysis and fermentation kinetics.

\section{Keywords}

Ethanol, Hydrolysis, Fermentation, Optimization, Kinetics

\section{Introduction}

In many parts of the world, demands for ethanol as an alternative source of energy have steadily increased due to efforts in decreasing the overall amount of greenhouse gases emitted into the atmosphere, dwindling fossil fuel resources, increased gasoline prices and the need to reduce the global unemployment rate [1]. Although

How to cite this paper: Igbokwe, P.K., Idogwu, C.N. and Nwabanne, J.T. (2016) Enzymatic Hydrolysis and Fermentation of Plantain Peels: Optimization and Kinetic Studies. Advances in Chemical Engineering and Science, 6, 216-235. 
ethanol is both solvent and fundamental feed stock for the synthesis of other products, it is also a safer alternative to Methyl Tertiary Butyl Ether (MTBE), the most common additive to gasoline used to provide cleaner combustions [2]. The United States Environmental Protection Agency (EPA) announced the beginning of regulatory action to eliminate MTBE in gasoline because it is a toxic chemical compound and has been found to contaminate ground water [2]. In order to encourage greater use of biofuel, European Union (EU) has set a target of $2 \%$ substitution of gasoline and diesel with biofuels in 2005 on an energy basis [3].

Obviously there is a growing interest for economical sustainable biofuel all over the world. In Nigeria, the use of waste lignocelluloses biomass for ethanol production has been the subject of many researches. The conversion of waste lignocelluloses in Nigeria will not only reduce the over dependence on petroleum based fuel, and diversify the economy, but will reduce the growing unemployment and sanitize the environment without affecting the human food chain [4]. Ethanol can be produced from lignocellulosic materials in various ways. All processes comprise the same main components: hydrolysis of the hemicellulose and the cellulose to monomer sugars, fermentation and product recovery and concentration by distillation. The main difference between the process alternatives is the hydrolysis steps, which can be performed by dilute acid, concentrated acid or enzyme.

The advantages of the enzymatic route over other chemical routes include higher yield, minimal by products formations, low energy requirements, mild operating conditions and environmentally friendly processing [5]. However, the enzymatic route has the highest cost at present but it has long term potential for cost reduction compared to other established routes such as the concentrated acid and the two stages dilute acid hydrolysis [6]. For the purpose of cost reduction in ethanol production, the use of cellulase producing micro organisms has been explored. Cellulase production among fungi is common and can be found in a large variety of species, including Trichoderma, Penicillum, and Aspergillus [7]. Compared with fungi, cellulolytic bacteria produce low amounts of cellulolytically active enzymes. Aspergillu sniger or A. niger is a fungus and one of the most common species of the genus Aspergillus [8]. A. niger was adopted as the crude enzyme for the hydrolysis of plantain peels in this study because it is easy to isolate and screen for cellulase activities.

Ighadaro [9] carried out studies on the content of the Nigerian species of Mada Paradisicia (plantain) peels and reported that the peels constitute about $40 \%$ (by weight) of the fruit, out of which $48.1 \%$ is carbohydrate. Itelima et al. [6], reported that only 3.98\% (v/v) of ethanol can be obtained from the same species of plantain peels. This quantity of ethanol cannot therefore be matched with the high percentage carbohydrate contained in plantain peels. There is therefore a need to employ a systematic study on the effect of the factors that could affect the yield of ethanol from plantain peels. This study therefore concentrated on two research gaps or research subjects: enzymatic hydrolysis of plantain peels and fermentation of plantain peels with the objective of modeling of subjects of research, optimization of the models and kinetics of the reactions involved.

\section{Materials and Methods}

\subsection{Raw Material Preparation}

\subsubsection{Preparation of Plantain Peels}

Ripped plantain peels obtained from Oye Market Emene Enugu, was chopped into small pieces and dried in an oven at $65^{\circ} \mathrm{C}$ for $48 \mathrm{hr}$ [1]. Part of the peels was dried under the sun. The dried substrate was powdered with an electric grinder to a mash size of $250 \mu \mathrm{m}$, packed in polyethylene bags and stored at room temperature for future use.

\subsubsection{Proximate Analysis of Plantain Peels}

The crude protein was analyzed using the Kjedal method and the fats and oils was measured using the Sohxlet method [9] [10]. The lignin and ash contents of the peels were measured by treating the peels with $72 \% \mathrm{w} / \mathrm{w}$ $\mathrm{H}_{2} \mathrm{SO}_{4}$ for 4.5 hrs. The suspension after the treatment with the acid was filtered through a crucible and the solid residue dried at $105^{\circ} \mathrm{C}$ for 24 hrs and weighed (W1). The residue was then transferred to a pre-weighed dry porcelain crucible and heated at $600^{\circ} \mathrm{C}$ for 5 hrs. After cooling down, it was weighed (W2) as the ash content. The lignin was calculated by the difference (W1-W2) [11].

The method of Kurschner-Hanack [12] was used to analyze for the concentration of cellulose/hemicelluloses in the plantain peels. This method was a gravimetric method where the weight of cellulose/hemicelluloses was measured when nitric acid and Acetic acid dissolved every other component of the plantain peels; cellulose/ 
hemicelluloses are insoluble in water, acetic acid and nitric acid. 1 gram of the plantain peel sample was measured in a round bottom flask. $15 \mathrm{ml}$ of $80 \%$ acetic acid and $1.5 \mathrm{ml}$ of raw nitric acid were added into the flask. The flask was connected to a reflux condenser and heated with a heating mantle for 2 hours. The solution after heating was filtered and the residue was washed and dried in an oven at $105^{\circ} \mathrm{C}$. The dried residue was weighed as the cellulose/hemicelluloses content of the sample.

\subsubsection{Isolation and Screening of Aspergillus niger (A. niger) for Cellulase Activities}

Aspergillus niger was isolated and screened for cellulase activities following the method prescribed by Ezonu et al., [8]. The isolated $A$. niger was thereafter multiplied by aseptically transferring a pinch of the fungus into different test tubes containing (potato dextrose ager) PDA mounted in slant positions.

\subsubsection{Inoculums for Hydrolysis}

$1 \%$ innoculum of the multiplied $A$. niger from a PDA slant was prepared by aseptically transferring $10 \mathrm{~g}$ of the pure and screened $A$. niger from the slant to a 1liter volumetric flask. Distilled water autoclaved at $121^{\circ} \mathrm{C}$ for 15 mins was added to make the mark of the flask. The mixture was left for 5 to 10 minutes at $150 \mathrm{rpm}$. The inoculums size was set to have a cell concentration of $1.0 \times 10^{8}$ cells per ml [8]. This inoculum was used for the whole hydrolysis experiment.

\subsubsection{Inoculums for Fermentation}

A commercial available dried form of industrial S. cerevisiae yeast was used in this research. For inoculum, 100 $\mathrm{ml}$ of distilled water was heated to $40^{\circ} \mathrm{C}$ in a shake flask and $0.5 \%(\mathrm{w} / \mathrm{w})$ of $S$. cerevisiae yeast was added to the warm water to activate the yeast. The mixture was left for 5 to $10 \mathrm{~min}$ at $150 \mathrm{rpm}$. The inoculums size was set to have a cell concentration of $5.3 \times 10^{7}$ cells per ml [13]. Dilution of the inoculums was done when the concentration of the cells was too high. One gram of yeast contained 25 billion of cells ( 25 billion/g yeast), thus the initial cell concentration was $2.12 \mathrm{~g} / \mathrm{L}$ [14].

\subsection{The Enzymatic Hydrolysis with A. niger}

The enzymatic hydrolysis was carried out in $250 \mathrm{~cm}^{3}$ conical flask containing $50 \mathrm{~cm}^{3}$ of $5 \%$ inoculums of $A$. niger with different dosage of the plantain peels and incubated on a shaker with an agitation rate of $300 \mathrm{rpm}$ at different temperatures for different time interval and at different $\mathrm{pH}$. The mixture was filtered and the soluble sugar yield in the filtrate was measured using the refractometer (Model RF M960 available at PRODA, Enugu) while the reducible sugar yield was determined using the DNS method [15]. The optimization experiment was carried out according to the design shown in Table 1 . The kinetics study was conducted by measuring the concentration of cellulose content of the peels with time.

\subsection{Fermentation of the Hydrolyzed Plantain Peels}

The fermentation was carried out in $250 \mathrm{~cm}^{3}$ conical flask containing $30-\mathrm{cm}^{3}$ of medium obtained from either enzymatic hydrolysis [14]. The medium was inoculated with 5\% (v/v) growth medium containing the activated Saccharomyces cerevisiae and incubated on a shaker with agitation rate of $300 \mathrm{rpm}$ at $30^{\circ} \mathrm{C}$ for 5 days at $\mathrm{pH}$ of 4.5 [6]. The effects of the operating parameters of temperature, $\mathrm{pH}$ and time were reported to be effective [6]. However the optimization of the fermentation process was carried out using a response surface methodology at temperature levels of $50^{\circ} \mathrm{C}, 70^{\circ} \mathrm{C}$ and $90^{\circ} \mathrm{C}$; pH levels of $6.5,7.5$ and 9.5 and time levels of 7 days, 9 days and 11 days. At the end of each run, the fermented liquor was decanted, distilled and the yield of ethanol measured.

\subsection{Distillation}

This was carried out using a simple distillation set up. The fermented liquid was transferred into round bottom flask and placed on a heating mantle fixed to a distillation column enclosed in running tap water. Another flask was fixed to the other end of distillation column to collect the distillate at $78^{\circ} \mathrm{C}$ [16].

\subsection{Determination of the Quantity of Ethanol Produced}

The distillate collected was measured using a measuring cylinder and expressed as quantity of ethanol produced 
Table 1. The CCRD design for the enzymatic hydrolysis.

\begin{tabular}{|c|c|c|c|c|c|c|}
\hline Factor & Symbol & -1 & 0 & +1 & -2.0 & +2.0 \\
\hline Temperature $\left({ }^{\circ} \mathrm{C}\right)$ & $\mathrm{X} 1$ & 28 & 35 & 42 & 21 & 49 \\
\hline Time (days) & $\mathrm{X} 2$ & 3 & 5 & 7 & 1 & 9 \\
\hline $\mathrm{pH}$ & X3 & 3.5 & 5.5 & 7.5 & 1.5 & 9.5 \\
\hline DOSAGE (g/50ml) & $\mathrm{X} 4$ & 5 & 8 & 11 & 2 & 14 \\
\hline No of core points $n_{j}$ & & & & & & \\
\hline No of starlike points $n_{\alpha}$ & & & & & & \\
\hline No of null points $n_{o}$ & & & & & & \\
\hline Total no of points $n$ & & & & & & \\
\hline
\end{tabular}

in g/l by multiplying the volume of the distillate by the density of ethanol [16].

Ethanol concentration was determined by comparing the density of the ethanol produced with the standard ethanol density curve [10] or by using a specific gravity meter (Model DA-130N, Available in PRODA, Enugu) which can measure the percentage ethanol directly.

\subsection{Optimization of the Enzymatic Hydrolysis}

Based on the result of the screening of factors, an optimization experiment was carried out to determine the optimum parameters for the enzymatic hydrolysis of plantain peels. The Central Composite Rotatable Design (CCRD) was applied for the optimization experiment. Table 1 shows the details of the experimental design [17].

\subsection{Optimization of the Fermentation Process}

An optimization experiment was carried out to obtain the optimum parameters for the fermentation of the hydrolyzed plantain peels. The Central Composite Rotatable Design (CCRD) was also used for this study. Table 2 shows the details of the design [17].

\subsection{Kinetics of Hydrolysis and Fermentation}

\subsubsection{The Kinetic Modeling of the Enzymatic Hydrolysis of Plantain Peels and Fermentation}

The kinetics model is based on the following theorems:

The rate of the reaction is given by the Equation (1)

$$
r_{\mathrm{A}}=-\frac{\mathrm{d} C_{\mathrm{A}}}{\mathrm{d} t}
$$

where $C_{A}$ is the concentration of the limiting reactant, in this case the limiting reactant is the cellulose and hemicelluloses content of the plantain peels.

The differential, $\frac{\mathrm{d} C_{\mathrm{A}}}{\mathrm{d} t}$ can be calculated by numerical method [18].

The numerical differential formula is used when the data points in the independent variable are equally spaced, such as: $t_{1}-t_{0}=t_{2}-t_{1}=\Delta t$. The three point-differential formula was applied in this work. Typically the tabulation of the concentration variation with time is as shown in Table 3.

The three-point differential formulae are presented in Equations (2)-(5):

$$
\begin{aligned}
& \text { Initial point: }\left(\frac{\mathrm{d} C_{A}}{\mathrm{~d} t}\right)_{t 0}=\frac{-3 C_{A 0}+4 C_{A 1}-C_{A 2}}{2 \Delta t} \\
& \text { Interior points: }\left(\frac{\mathrm{d} C_{A}}{\mathrm{~d} t}\right)_{t i}=\frac{1}{2 \Delta t}\left[C_{A(i+1)}-C_{A(i-1)}\right]
\end{aligned}
$$


Table 2. The CCRD design for the optimization of the fermentation reaction.

\begin{tabular}{ccccccc}
\hline Factor & Symbol & -1 & 0 & +1 & -1.68 & +1.68 \\
\hline Temperature $\left({ }^{\circ} \mathrm{C}\right)$ & $\mathrm{X} 1$ & 30 & 40 & 50 & 23 & 56.8 \\
Time (days) & $\mathrm{X} 2$ & 3 & 6 & 6 & 8 & 11 \\
$\mathrm{pH}$ & $\mathrm{X} 3$ & & 4 & & & \\
No of core points $n_{j}$ & & 8 & & & & \\
No of starlike points $n_{\alpha}$ & & 6 & & & & \\
No of null points $n_{0}$ & & 6 & & &
\end{tabular}

Table 3. Typical tabulation for concentration variation with time.

\begin{tabular}{|c|c|c|c|c|c|c|}
\hline Time (hrs) & $t_{0}$ & $t_{1}$ & $t_{2}$ & $t_{3}$ & $t_{4}$ & $t_{5}$ \\
\hline$C_{A}\left(\mathrm{~g} / \mathrm{dm}^{3}\right)$ & $\mathrm{C}_{\mathrm{A} 0}$ & $\mathrm{C}_{\mathrm{A} 1}$ & $\mathrm{C}_{\mathrm{A} 2}$ & $\mathrm{C}_{\mathrm{A} 3}$ & $\mathrm{C}_{\mathrm{A} 4}$ & $\mathrm{C}_{\mathrm{A} 5}$ \\
\hline
\end{tabular}

$$
\begin{aligned}
& {\left[\text { eg. }\left(\frac{\mathrm{d} C_{A}}{\mathrm{~d} t}\right)_{t 3}=\frac{1}{2 \Delta t}\left[C_{A(4)}-C_{A(3)}\right]\right]} \\
& \text { Last point: }\left(\frac{\mathrm{d} C_{A}}{\mathrm{~d} t}\right)_{t 5}=\frac{1}{2 \Delta t}\left[C_{A 3}-4 C_{A 4}+3 C_{A 5}\right]
\end{aligned}
$$

Equations (2)-(5) were used to calculate the change in the reactant concentration with time $\frac{\mathrm{d} C_{A}}{\mathrm{~d} t}$.

The method of Kurschner-Hanack [12] was used to analyze for the concentration of cellulose and hemicellulose in the plantain peels.

This method is a gravimetric method where the weight of cellulose and hemicellulose is measured when nitric acid and Acetic acid dissolved every other component of the plantain peels; cellulose and hemicellulose are insoluble in water, acetic acid and nitric acid.

1 gram of the plantain peel sample is measured in a round bottom flask. $15 \mathrm{ml}$ of $80 \%$ acetic acid and $1.5 \mathrm{ml}$ of raw nitric acid are added into the flask. The flask is connected to a reflux condenser and heated with a heating mantle for 2 hours. The solution after heating is filtered and the residue is washed and dried in an oven at $105^{\circ} \mathrm{C}$. The dried residue is weighed as the cellulose and hemiccellulose content of the sample.

\subsubsection{The Michaelis-Menten Model}

The form of the Michaelis-Menten kinetic equation is given as in Equation (6) [18]:

$$
-r_{A}=\frac{V_{\max }(S)}{K_{m}+(S)}
$$

where $r_{A}=$ the rate of the enzymatic reaction;

$V_{\max }=$ the maximum rate of the reaction for a given total enzyme concentration;

$K_{m}=$ the Michaelis-Menten constant;

$S=$ the substrate concentration.

The linear form of the model is given in Equation (7)

$$
-\frac{1}{r_{s}}=\frac{1}{V_{\max }}+\frac{K_{m}}{V_{\max }}\left(\frac{1}{S}\right)
$$

The plot of $-\frac{1}{r_{s}}$ against $\left(\frac{1}{S}\right)$ gives a straight line where $V_{\max }$ and $K_{m}$ can be calculated from the intercept and the slope respectively. 


\section{Results and Discussion}

\subsection{The Composition of Plantain Peels}

The results of the proximate analysis shown in Table 4 confirmed that plantain peels is reach in cellulose/ hemicelluloses which can be converted to ethanol. The values agree closely with the work done by Ighodaro [9], which reported that the cellulose content of ripe plantain peels is $42.95 \%$ while that of the unripe plantain peels is $48.18 \%$.

\subsection{Enzymatic Hydrolysis of Plantain Peels}

\subsubsection{The Analysis of Variance (ANOVA) for Hydrolysis}

The optimization of the hydrolysis of plantain peels using quadratic model of Response Surface or Central Composite Design of experiment gave a significant model; the results of the second order response surface model in the form of analysis of variance (ANOVA) are given in Table 5. The Fisher $F$-test with a very low probability value ( $p$ model $>F<0.000001$ ) demonstrate a high significance for the regression model [19]. The goodness of fit of the model was checked by the determination coefficient $\left(R^{2}\right)$. In this case, the value of the determination coefficient $\left(R^{2}=0.9330\right)$ indicates that only $6.7 \%$ of the total variations are not explained by the model. A high value of the correlation coefficient, $\left(R^{2}=0.9330\right)$ justifies an excellent correlation between the independent variables. The value of the adjusted determination coefficient (Adj. $R^{2}=0.87004$ ) is also high to advocate for a high significance of the model [19]. At the same time a relatively lower value of the coefficient of variation ( $\mathrm{CV}=7.06 \%)$ indicates a better precision and reliability of the experiments carried out. The "Lack of Fit F-value" of 1.79 implies the Lack of Fit is not significant relative to the pure error. There is a $26.96 \%$ chance that a "Lack of Fit F-value" this large could occur due to noise. Non-significant lack of fit is good-we want the model to fit. The model equations for hydrolysis in terms of the actual factor with all the terms and without the insignificant terms are given in Equations (8) and (9) respectively.

\subsubsection{Mathematical Model Equation of Hydrolysis (in Terms of the Actual Factors)}

$$
\begin{aligned}
\text { Glucoseyield }(\%) & =79-2.6 A+1.1 B-0.6 C-3.5 D+0.03 A B+0.04 A C+0.04 A D+0.0 B C-0.08 B D \\
& +0.02 C D+0.02 A^{2}+0.11 B^{2}-0.02 C^{2}+0.17 D^{2}
\end{aligned}
$$

where $A=$ temperature $\left({ }^{\circ} \mathrm{C}\right), B=$ time (days), $C=\mathrm{pH}$ and $D=$ substrate concentration $(\mathrm{g} / 30 \mathrm{ml})$.

Deleting the non significant terms, the model equation reduces to:

$$
\text { Glucoseyield }(\%)=79-2.6 A+1.1 B-0.6 C-3.5 D+0.04 A D+0.02 A^{2}+0.17 D^{2} \text {. }
$$

\subsubsection{Verification of the Optimum Numerical Solution for Hydrolysis}

According to Tengborg et al., [20], it is not possible to define a single optimum for enzymatic processes since it can change depending on the level of other factors; however one of the optimum solutions was selected as shown in the Table 6 . The result of the verification of the optimum numerical solution showed that the optimum solution predicted the real solution closely. The deviation of the experimental yield of glucose from the predicted yield was only $6.1 \%$ which was a close match.

Table 4. The composition of plantain peels.

\begin{tabular}{cc}
\hline Component & \% Composition \\
\hline Lignin & 25.7 \\
Crude protein & 6.8 \\
Cellulose/hemicelluloses & 46.5 \\
Ash & 5.9 \\
Moisture & 7.8 \\
Fats and oil & 7.3 \\
\hline
\end{tabular}


Table 5. The ANOVA table for the hydrolysis.

\begin{tabular}{|c|c|c|c|c|c|c|}
\hline Source & $\begin{array}{l}\text { Sum of } \\
\text { squares }\end{array}$ & df & $\begin{array}{l}\text { Mean } \\
\text { square }\end{array}$ & F value & $\begin{array}{c}\text { p-value } \\
\text { Prob }>\text { F }\end{array}$ & Remarks \\
\hline Model & 436.13 & 14 & 31.15 & 14.91 & $<0.0001$ & significant \\
\hline A-Temperature & 170.67 & 1 & 170.67 & 81.70 & $<0.0001$ & \\
\hline B-Time & 28.17 & 1 & 28.17 & 13.48 & 0.0023 & \\
\hline$C-p H$ & 73.50 & 1 & 73.50 & 35.19 & $<0.0001$ & \\
\hline D-Substrate Conc & 32.67 & 1 & 32.67 & 15.64 & 0.0013 & \\
\hline$A B$ & 4.00 & 1 & 4.00 & 1.91 & 0.1867 & \\
\hline$A C$ & 6.25 & 1 & 6.25 & 2.99 & 0.1042 & \\
\hline$A D$ & 12.25 & 1 & 12.25 & 5.86 & 0.0286 & \\
\hline$B C$ & $5.684 \mathrm{E}-014$ & 1 & $5.684 \mathrm{E}-014$ & $2.721 \mathrm{E}-014$ & 1.0000 & \\
\hline$B D$ & 4.00 & 1 & 4.00 & 1.91 & 0.1867 & \\
\hline$C D$ & 0.25 & 1 & 0.25 & 0.12 & 0.7342 & \\
\hline$A^{2}$ & 29.76 & 1 & 29.76 & 14.25 & 0.0018 & \\
\hline$B^{2}$ & 5.76 & 1 & 5.76 & 2.76 & 0.1175 & \\
\hline$C^{2}$ & 0.19 & 1 & 0.19 & 0.091 & 0.7668 & \\
\hline$D^{2}$ & 65.19 & 1 & 65.19 & 31.21 & $<0.0001$ & \\
\hline Residual & 31.33 & 15 & 2.09 & & & \\
\hline Lack of Fit & 24.50 & 10 & 2.45 & 1.79 & 0.2696 & Not significant \\
\hline Pure Error & 6.83 & 5 & 1.37 & & & \\
\hline Cor Total & 467.47 & 29 & & & & \\
\hline
\end{tabular}

Std. Dev $=1.45$, Mean $=20.47$, C.V $\%=7.06$, PRESS $=150.96$, R-Square $=0.9330$, Adj R-Squared $=0.8704$, Pred R-Squared $=0.6771$, Adeq Precision $=16.145$.

\section{Table 6. Optimization numerical solution.}

\begin{tabular}{ccccccc}
\hline Factors & Temp $\left({ }^{\circ} \mathrm{C}\right)$ & Time (days) & $\mathrm{pH}$ & $\begin{array}{c}\text { Subs. conc } \\
(\mathrm{g} / 30 \mathrm{ml})\end{array}$ & $\begin{array}{c}\text { Glucose yield } \\
\% \text { (predicted) }\end{array}$ & $\begin{array}{c}\text { Yield (\%) } \\
\text { experimental }\end{array}$ \\
\hline Optimum & 35.000 & 5.000 & 5.500 & 8.000 & 52.3 & 49.1 \\
\hline
\end{tabular}

The graph of the predicted against the actual values shown in Figure 1 also confirmed the closeness of the predicted values and the actual values. The data points of the optimization runs fall along the diagonal of the squared graph showing the close relationship of the predicted and the actual points. In other words, the quadratic model was adequate for the analysis.

\subsubsection{Factors and Interactive Effects on Hydrolysis}

The contour and 3D graphs of Figures 2-7 show the factors and the interactive effects on the yield of simple sugar (Glucose).

1) The effect of temperature

The relationship between temperature and glucose yield was seen to be inverse. The yield of glucose decreases with the temperature and the optimum was seen at around $35^{\circ} \mathrm{C}$. At a temperature level from the ambient to $35^{\circ} \mathrm{C}$, the glucose yield increased considerably and decreased at a higher temperature. The effect of temperature on the yield of glucose was however significant as confirmed in Table 5. 
Design-Expert $\circledast$ Software Glucose yield

Color points by value of Glucose yield:

$7_{13}^{27}$

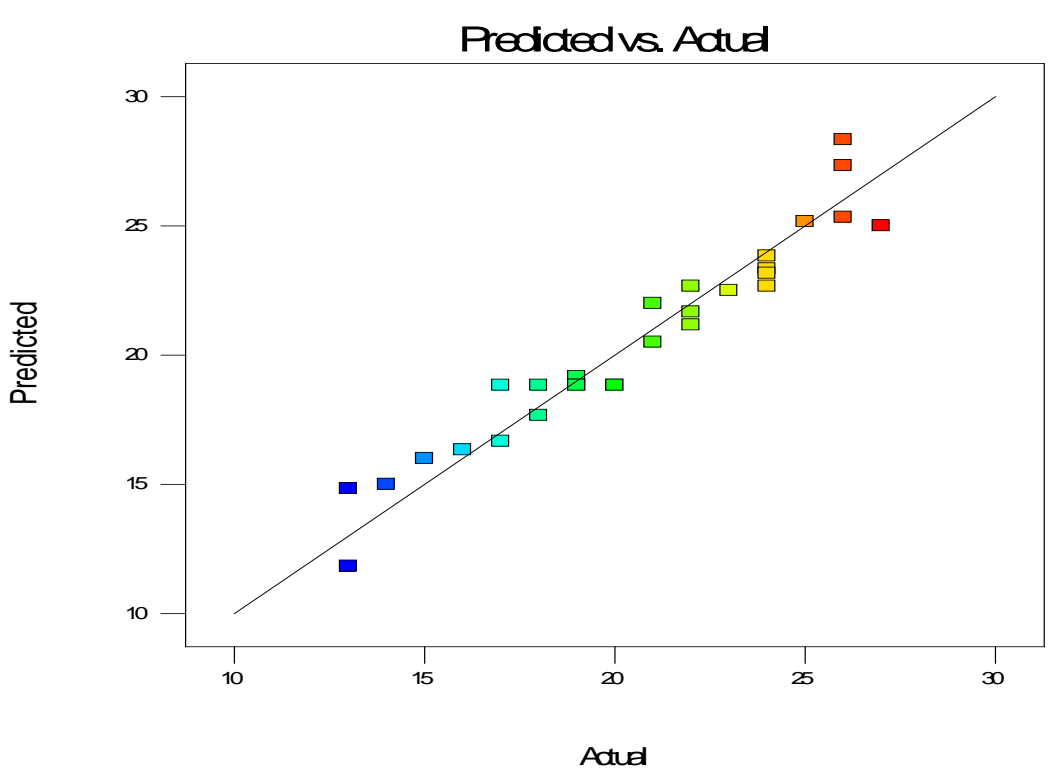

Figure 1. The plot of the predicted values against the actual values for hydrolysis optimization.

Design-Expert $₫$ Software

Factor Coding: Actual

Glucose yield (\%)

- Design Points

$\prod_{13}^{27}$

$\mathrm{X} 1=\mathrm{A}:$ Temperature

X2 = B: Time

Actual Factors

D: Substrate Conc $=8$

* Intervals adjusted for

variation in the factors

** Predictions adjusted fo

variation in the factors

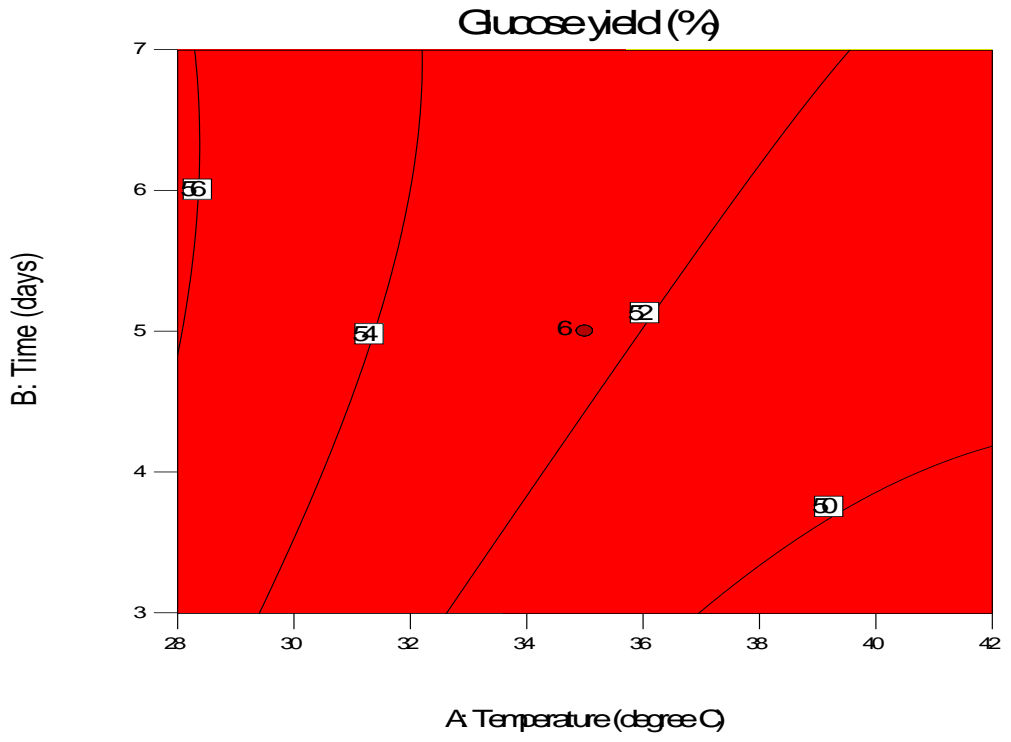

Design-Expert® Software

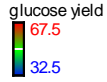

$\mathrm{X} 1=\mathrm{A}:$ temperature

$\mathrm{X} 1=\mathrm{A}:$ temper
$\mathrm{X} 2=\mathrm{B}$ : time

Actual Factors
$\mathrm{C}: \mathrm{pH}=5.50$
D: concentration $=8.00$

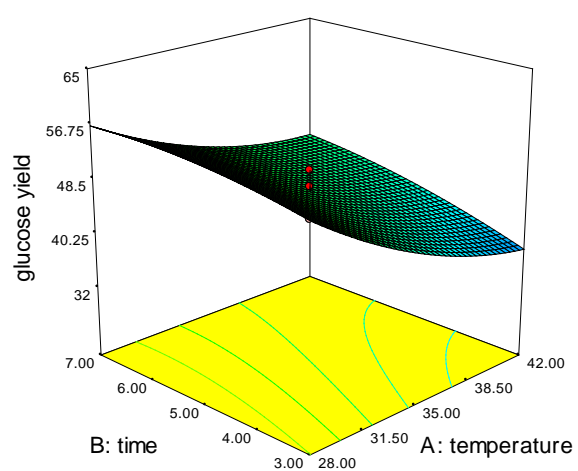

Figure 2. The contour and 3D plots of time against temperature. 

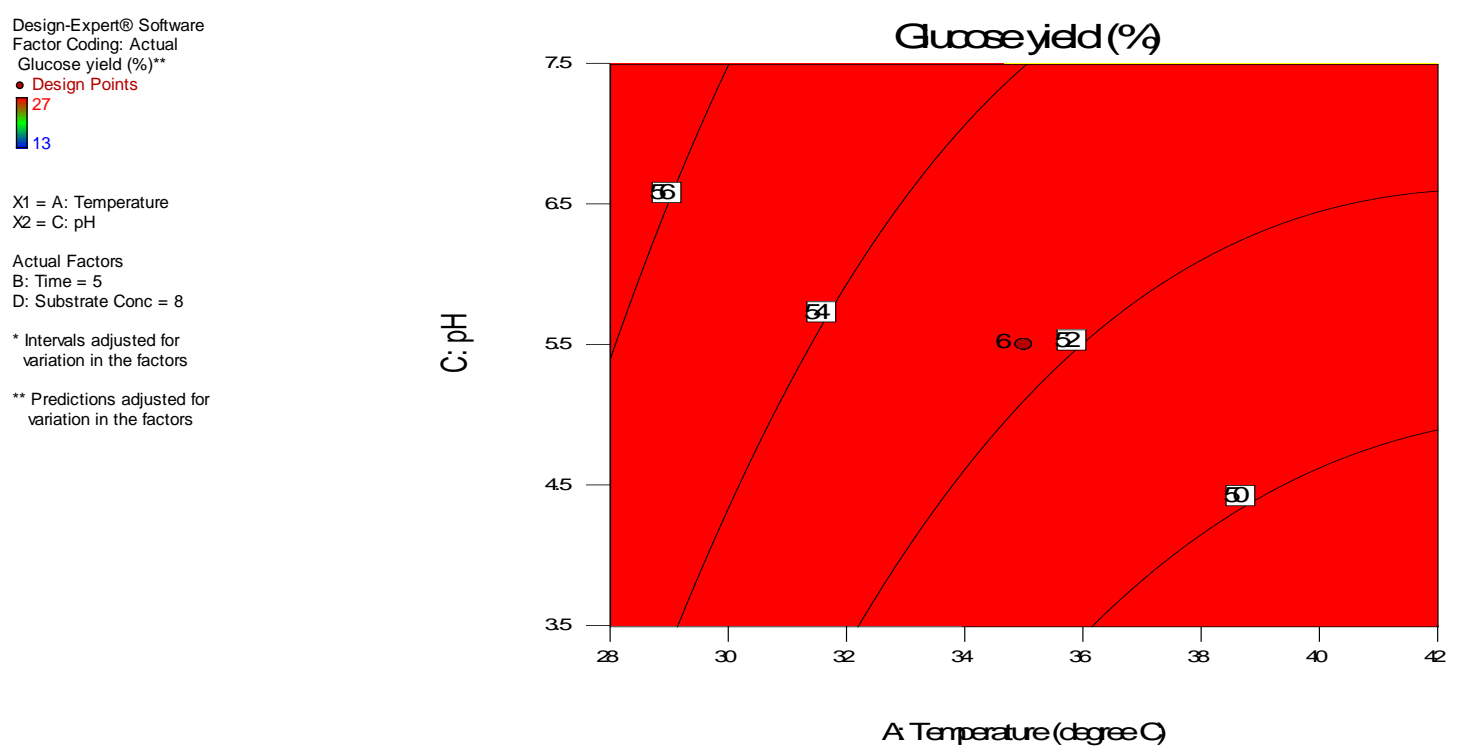

Design-Expert@ Software
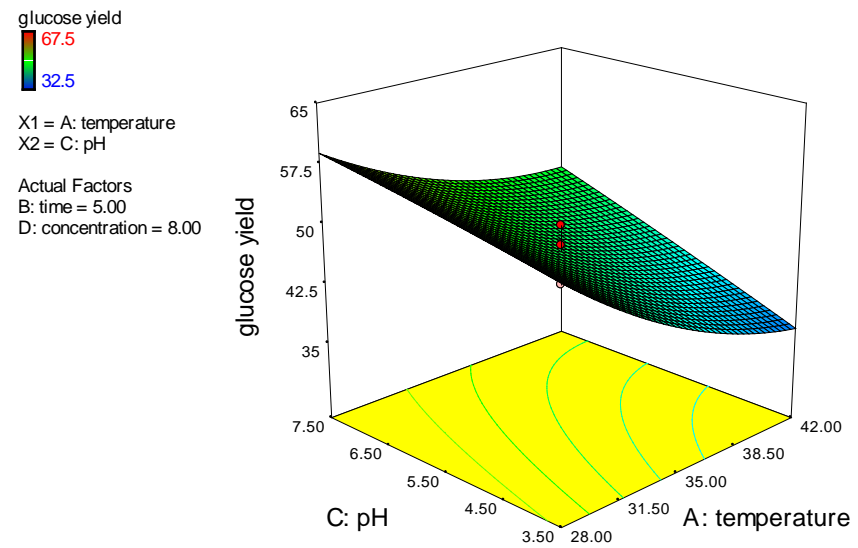

Figure 3. The contour and 3D plots of $\mathrm{pH}$ against temperature.

Temperature has effective interaction with other factors however only the interaction with the substrate concentration was significant (Table 5). This significant interaction can be seen in Figure 4 where the contour plot of temperature against substrate concentration is somewhat curves in contrast to Figure 2 and Figure 3 where the contour plots of temperature against $\mathrm{pH}$ and time are somewhat straight lines showing non-significant interactions. Figures 2-4 show that irrespective of any interaction, the highest glucose yield can be achieved at room temperature.

Zapkaa et al. [21] reported that the optimum temperature for hydrolysis using A. niger as a crude enzyme on corncobs was $40^{\circ} \mathrm{C}$ and stated that there was a sharp decrease in the rate of hydrolysis from $50^{\circ} \mathrm{C}$ to $60^{\circ} \mathrm{C}$ due to the fact that enzyme denaturation was faster. He stated that the hydrolysis increases with temperature up to the optimum which it declined and that the increase in temperature is due to corresponding increase in kinetic energy and the decline after the optimum is due to enzyme denaturation. Galbe and Zacchi [7] stated that the optimum temperature for hydrolysis of cellulosic materials using pure enzymes lie between $45^{\circ} \mathrm{C}$ to $50^{\circ} \mathrm{C}$.

2) The effect of $\mathrm{pH}$

The contour and 3D plots of Figure 3, Figure 5 and Figure 7 show that the $\mathrm{pH}$ of the solution greatly affected the yield of glucose during hydrolysis. From a pH of 3.5 to a $\mathrm{pH}$ of 8 , the yield of glucose was seen to vary considerably. This can also be seen from Table 5 (the ANOVA table) where the effect of pH is significant. Below the optimum $\mathrm{pH}$ to the optimum $\mathrm{pH}$ the rate of the increase in glucose yield with $\mathrm{pH}$ was higher than the rate of decrease above the optimum $\mathrm{pH}$. 


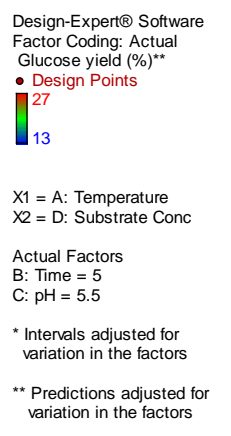

Factor Coding: Actual

Glucose yield (\%)

- Design Poi

(3)

Actual Factors

$\mathrm{C}: \mathrm{pH}=5.5$

Predictions adjusted for
variation in the factors

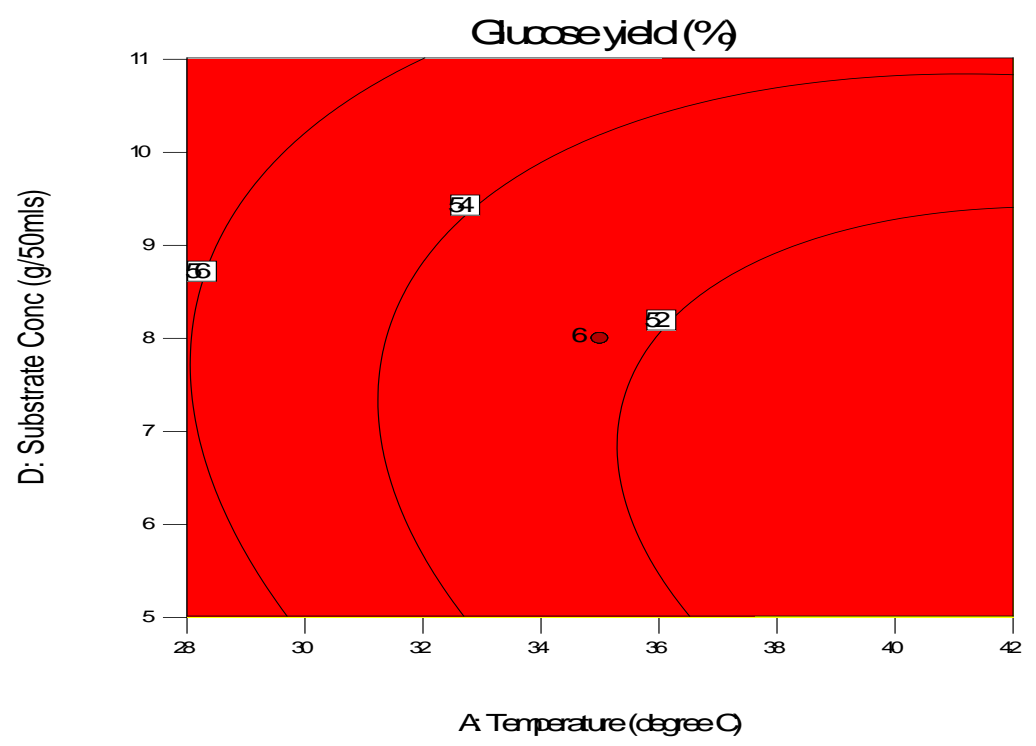

Design-Expert® Software
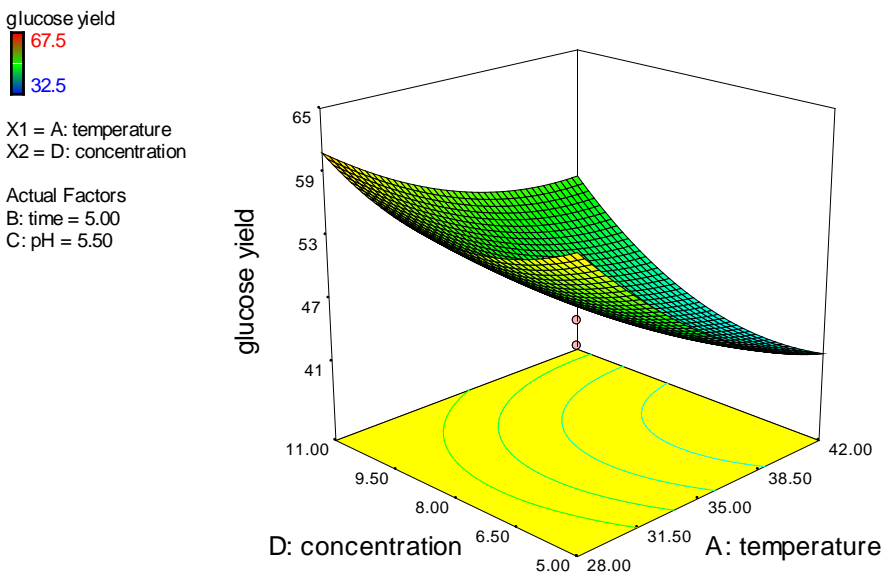

Figure 4. The contour and 3D plots of substrate concentration against temperature.

The interactive effects of the $\mathrm{pH}$ with other factors were not significant. This was shown in Table 5 where the p-values are greater than 0.05. This can also be seen on the contour graphs (Figure 3, Figure 5 and Figure 7) where the contour plots of $\mathrm{pH}$ with temperature, time and substrate concentration are somewhat straight lines at some points. Figure 3 shows that between $\mathrm{pH}$ of 5.5 and 7.5, the temperature should be kept below $30^{\circ} \mathrm{C}$ to get $56 \%$ yield of glucose and between $\mathrm{pH}$ of 3.5 and 5.0 , the temperature can be maintained at $30^{\circ} \mathrm{C}$ to $40^{\circ} \mathrm{C}$ to get $50 \%$ glucose yield. Figure 5 and Figure 7 show that as the $\mathrm{pH}$ increases, both time of incubation and substrate concentration should be keep high to get higher glucose yield.

Akponah and Akpomie [22] reported that the A. niger hydrolysis activities increases from a pH of 4.5 to 5.5 and decreases at a pH of 6.5. The $\mathrm{pH}$ of the solution has effects on the structure and activity of the enzyme. Enzymes are amphoteric molecules containing a large number of acid and basic groups mainly situated on their surface. The charges on this group vary, according to their acid dissociation constant, with the $\mathrm{pH}$ of the solution [21].

3) The effect of substrate concentration

The substrate concentration is the amount of plantain peels (g) that was soaked into $30 \mathrm{ml}$ of the inoculums of A. niger prepared as shown in Section 2.3.

Table 5 confirms that that substrate concentration had a significant effect on the yield of glucose $(\mathrm{p}<0.05)$. Below the optimum value, Figure 4 shows that the rate of the increase in glucose yield with substrate 
Design-Expert $₫$ Software

Factor Coding: Actual

Glucose yield (\%)

- Design Points

27

$\mathrm{X}_{1}=\mathrm{B}:$ Time
$\mathrm{X}_{2}=\mathrm{C}: \mathrm{pH}$

Actual Factors

A: Temperature $=35$

D: Substrate Conc $=8$

* Intervals adjusted for variation in the factors

** Predictions adjusted for variation in the factors

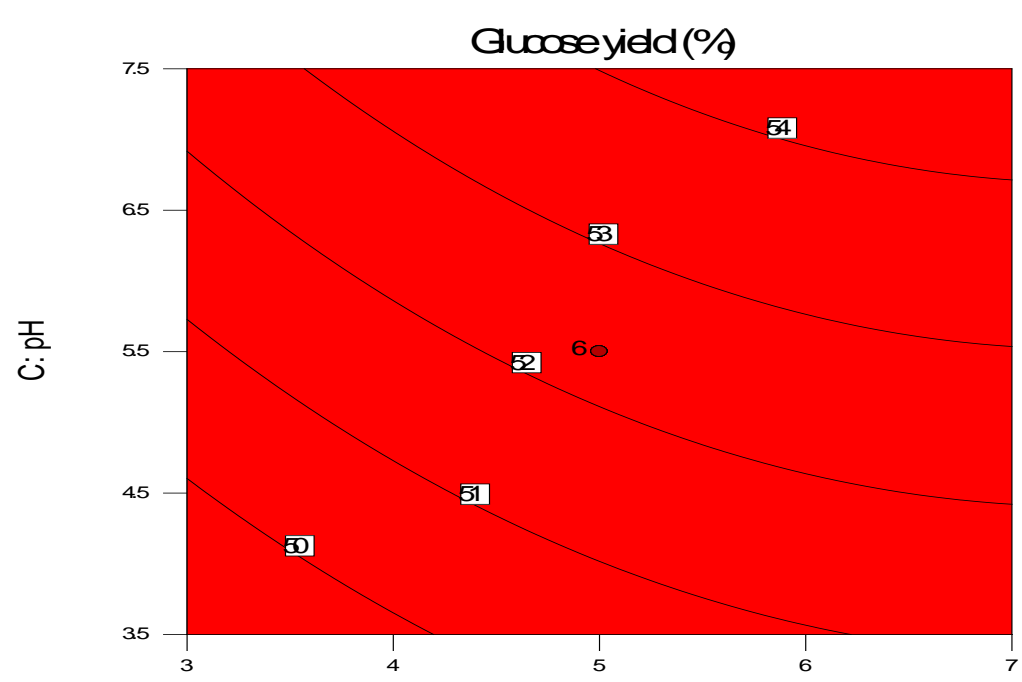

B Time(days)

Design-Expert@ Software

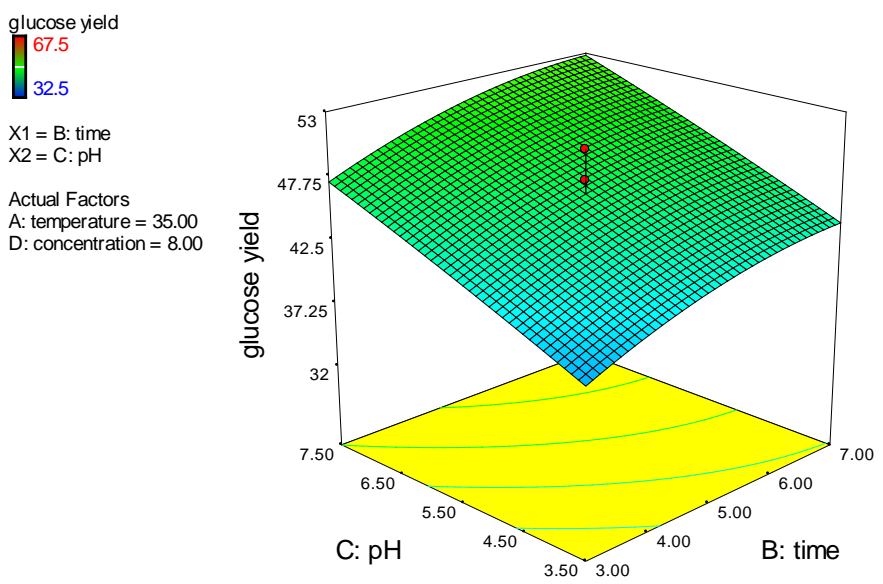

Figure 5. The contour and 3D plots of $\mathrm{pH}$ against time.

concentration was higher than the rate at a substrate concentration close to the optimum value. The rate of the glucose decrease above the optimum value of concentration was low.

Zapkaa et al. [21] also reported that the optimum substrate concentration for A. niger hydrolysis of corncobs was $6 \%$ and explained that before the optimum concentration, random collision between the substrate and enzyme active sites happen more frequently but beyond the optimum the active sites are saturated so higher concentration have no effect on the hydrolysis rate.

Substrate concentration had a significant interaction with temperature (Figure 4). The contour plots of substrate concentration with other factors show somewhat straight line plots which is an evident of a non-significant interaction (Figure 6 and Figure 7). It can also be seen from Figure 6 that high substrate concentration requires more time of incubation to achieve high glucose yield.

4) The effect of time

From the selected optimum solution, the optimum time of the hydrolysis reaction was 5 days. This can also be seen from the result of the kinetics study shown in Table 9. Here the rate of the decomposition of cellulose on day 0 to day 4 decreased steadily and afterwards it became almost constant. Time however had a significant effect on the yield of glucose in hydrolysis. Table 5 shows that the p value of time was less than 0.05 .

Zakpaa et al. [21] reported that there was an increase in enzyme activities from 24 to $144 \mathrm{~h}$ after incubation and stated that cellulose is an induced enzyme hence its production increases with increase in fungal biomass 
Design-Expert@ Software Factor Coding: Actual Glucose yield (\%) - Design Points

27

$X 1=B:$ Time $\mathrm{X}_{2}=\mathrm{D}:$ Substrate Conc

Actual Factors

A: Temperature $=35$

C: $\mathrm{pH}=5.5$

* Intervals adjusted for variation in the factors

** Predictions adjusted for variation in the factors

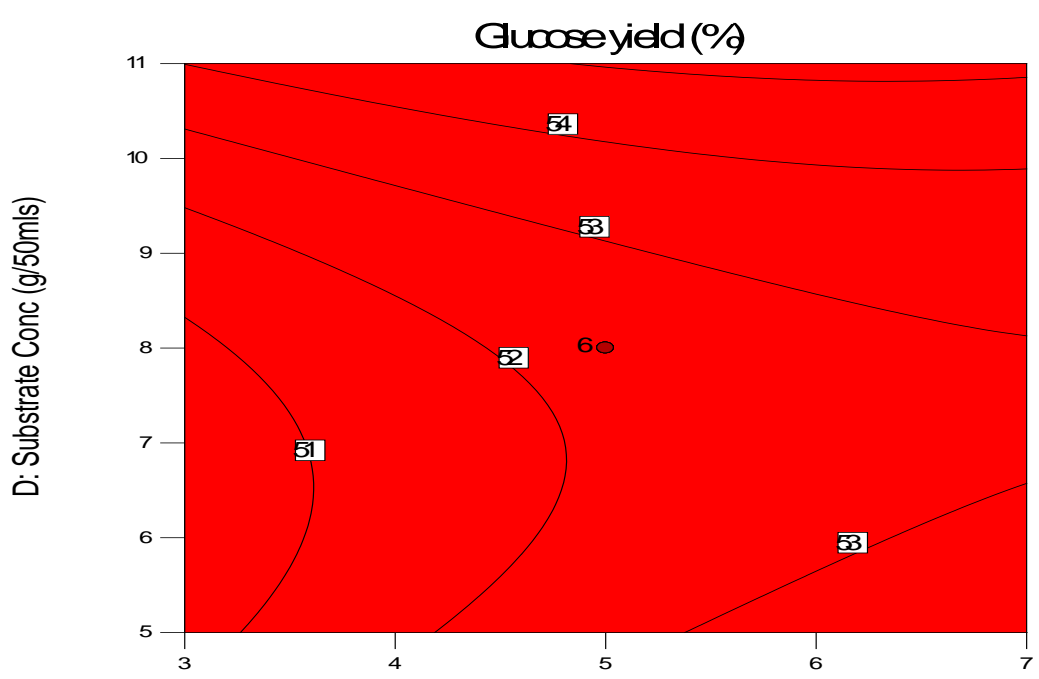

B Tirre(days)

Design-Expert ${ }^{\circledR}$ Software

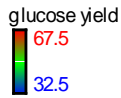

$\mathrm{X} 1=\mathrm{B}:$ time $\mathrm{X} 2=\mathrm{D}:$ concentration

Actual Factors A: temperature $=35.00$ $\mathrm{C}: \mathrm{pH}=5.50$

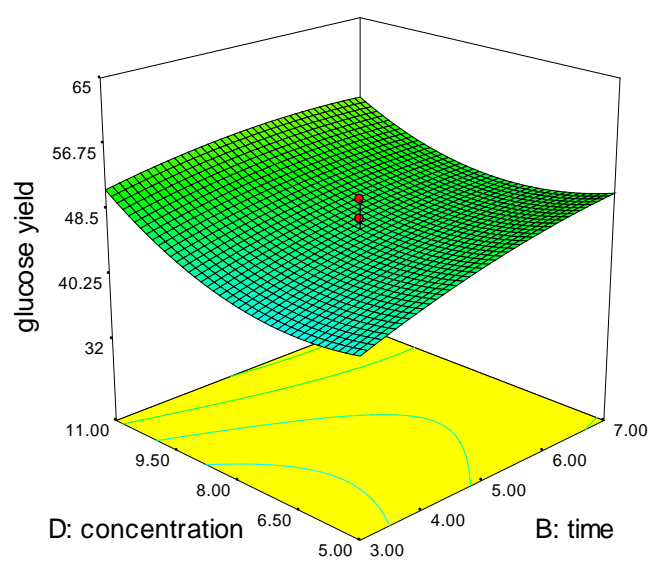

Figure 6. The contour and 3D plots of substrate concentration against time.

over the incubation period. Akponah and Akpomie [22] reported that the rate of saccharification where Aspergilus niger was used increased with the incubation period. They reported that the highest value of simple sugar was obtained on the $7^{\text {th }}$ day of incubation and suggested that hydrolysis is dependent on the growth kinetics of the fungus.

\subsection{Optimization of the Fermentation Process}

\subsubsection{The Analysis of Variance for Fermentation}

The optimization of the fermentation experiment was carried out using the Central Composite Rotatable Design or the Box-Wilson design. The model of the experiment used was quadratic model. The Model F-value of 57.25 implies the model is significant. There is only a $0.01 \%$ chance that an F-value this large could occur due to noise. Values of "Prob > F" less than 0.0500 indicate model terms are significant. In this case A, B, C, AB, AC, A ${ }^{2}, B^{2}$, $\mathrm{C}^{2}$ are significant model terms. Values greater than 0.1000 indicate the model terms are not significant. The goodness of fit of the model was checked by the determination coefficient $\left(R^{2}\right)$ (Table 7$)$. In this case, the value of the determination coefficient $\left(R^{2}=0.9810\right)$ indicates that only $1.4 \%$ of the total variations are not explained by the model. A higher value of the correlation coefficient, $\left(R^{2}=0.9810\right)$ justifies an excellent correlation between the independent variables. The value of the adjusted determination coefficient (Adj. $R^{2}=0.9638$ ) is also 
Design-Expert® Software Factor Coding: Actual Glucose yield (\%) - Design Point

$\prod_{13}^{27}$

$\mathrm{X} 1=\mathrm{C}: \mathrm{pH}$

$\mathrm{X}_{2}=\mathrm{D}:$ Substrate Conc

Actual Factors

A: Temperature $=35$

* Intervals adjusted for variation in the factors

** Predictions adjusted for variation in the factors

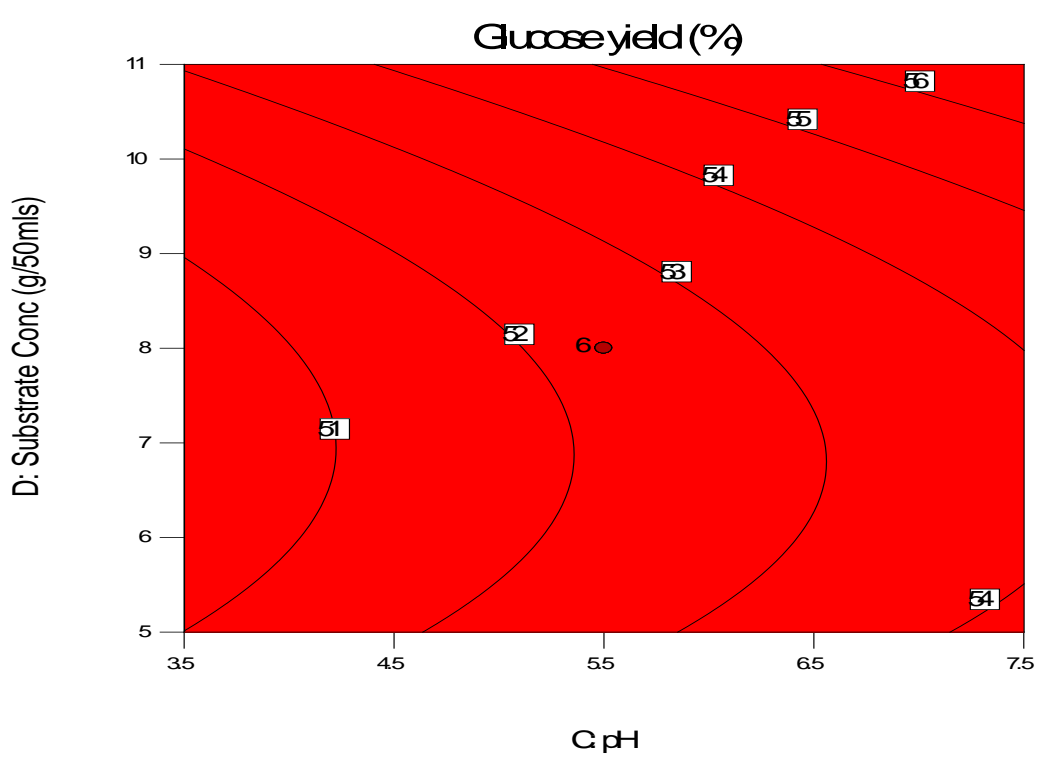

Design-Expert® Software

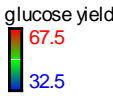

$\mathrm{X} 1=\mathrm{C}: \mathrm{pH}$ $\mathrm{X}_{2}=\mathrm{D}:$ concentration

Actual Factors A. temperature $=35.00$ B: time $=5.00$

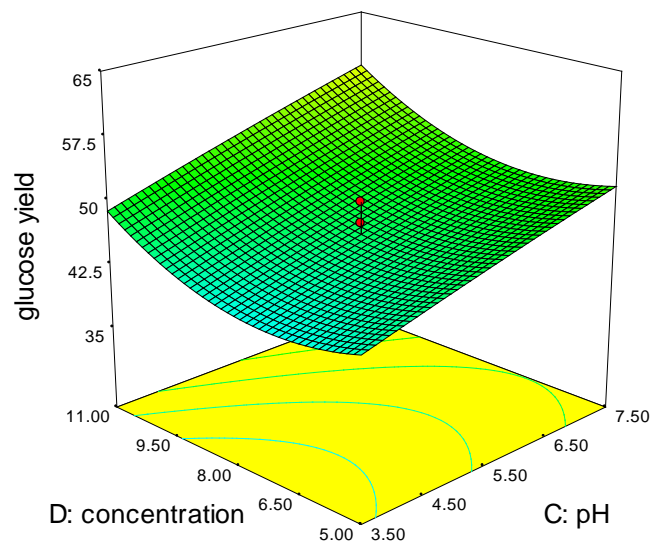

Figure 7. The contour graph of substrate concentration against $\mathrm{pH}$.

high to advocate for a high significance of the model [19]. At the same time a relatively lower value of the coefficient of variation $(\mathrm{CV}=7.06 \%$ ) indicates a better precision and reliability of the experiments carried out. The "Lack of Fit F-value" of 0.21 implies the Lack of Fit is not significant relative to the pure error. There is a $26.96 \%$ chance that a "Lack of Fit F-value" this large could occur due to noise. Non-significant lack of fit is good-we want the model to fit. The model equations in terms of the actual values with all the terms and without the insignificant terms are shown in Equations (10) and (11) respectively.

\subsubsection{Mathematical Model Equation for Fermentation (in Terms of the Actual Factors)}

$$
\text { Ethanolyield } \begin{aligned}
(\%) & =79.75-1.91 A-5.87 B-1.8 C \\
& +0.09 A B+0.03 A C+0.016 B C+0.013 A^{2}+0.199 B^{2}+0.044 C^{2}
\end{aligned}
$$

Removing the non significant term, the model equation reduces to:

$$
\begin{aligned}
\text { Ethanolyield }(\%) & =31.9-0.763 A-2.35 B-0.72 C+0.04 A B \\
& +0.01 A C+0.005 A^{2}+0.08 B^{2}+0.02 C^{2}
\end{aligned}
$$

where $A=$ temperature $\left({ }^{\circ} \mathrm{C}\right), B=\mathrm{pH}$ and $C=$ time (days). 
Table 7. The ANOVA table of the fermentation optimization.

\begin{tabular}{ccccccc}
\hline Source & Sum of squares & df & Mean square & F value & p-value Prob $>$ F \\
\hline Model & 14.60 & 9 & 1.62 & 57.25 & $<0.0001$ & Significant \\
A-temperature & 1.20 & 1 & 1.20 & 42.48 & $<0.0001$ \\
$B-p H$ & 0.77 & 1 & 0.77 & 27.22 & 0.0004 \\
C-Time & 1.56 & 1 & 1.56 & 55.00 & $<0.0001$ \\
$A B$ & 4.35 & 1 & 4.35 & 153.54 & $<0.0001$ \\
$A C$ & 1.53 & 1 & 1.53 & 54.03 & $<0.0001$ \\
$B C$ & 0.011 & 1 & 0.011 & 0.40 & 0.5428 \\
$A^{2}$ & 4.05 & 1 & 4.05 & 142.93 & $<0.0001$ \\
$B^{2}$ & 1.46 & 1 & 1.46 & 51.43 & $<0.0001$ \\
$C^{2}$ & 0.36 & 1 & 0.36 & 12.84 & 0.0050 \\
Residual & 0.28 & 10 & 0.028 & & \\
Lack of fit & 0.21 & 5 & 0.042 & 2.78 & \\
Pure error & 0.075 & 5 & 0.015 & & \\
Cor total & 14.89 & 19 & & & Not significant
\end{tabular}

Std. Dev $=0.17$, Mean $=8.23$, C.V. $\%=2.04$, PRESS $=1.69$, R-Squared $=0.9810$, Adj. R-Squared $=0.9638$, Pred R-Squared $=0.8863$, Adeq Precision $=29.411$.

\subsubsection{Verification of the Numerical Optimum Solution for Fermentation}

Table 8 shows that the predicted value was close to the actual experimental value at the optimum condition. The deviation of the experimental from the predicted was only $6.5 \%$. The graph of the predicted against the actual shown below also confirms that the prediction was accurate. The adequacy of the model can also be seen in Figure 8 where the actual points lie along the diagonal.

\subsubsection{Factors and Interactive Effects on Fermentation}

The interactive effects of the factors for fermentation are shown by the contour and 3D plots of Figures 9-11.

1) The effect $\mathrm{pH}$ on fermentation

$\mathrm{pH}$ of the solution is a significant factor of fermentation ( $\mathrm{p}$ value $<0.0001$, Table 7 ). The optimum $\mathrm{pH}$ is 4 (Table 8). From Figure 9, it can be seen that the percentage yield of ethanol remained somewhat constant at a $\mathrm{pH}$ of 4 to 6.9 and the rate of decrease increases at a $\mathrm{pH}$ above 7. $\mathrm{pH}$ had an interactive effect with time and temperature. The interaction of $\mathrm{pH}$ with time was however not significant $(\mathrm{p}=0.5428)$. This can be seen from contour graph of Figure 11. The interaction of $\mathrm{pH}$ with temperature was significant $(\mathrm{p}<0.05)$. The contour plots of $\mathrm{pH}$ against temperature shown in Figure 9 are all curves showing the significant effect of the interaction.

Abah et al. [13] reported that the optimum $\mathrm{pH}$ for fermentation using wild strain Saccharomyces cerevisiae is 3.7. Highina et al. [23] reported that the optimum temperature and $\mathrm{pH}$ for fermentation is $30^{\circ} \mathrm{C}$ and 4.5 respectively and stated that there is excessive enzyme degradation and loss of cell viability at $\mathrm{pH}$ and temperature above the optimum. Also, Lebaka et al. [24] reported that the optimum $\mathrm{pH}$ and temperature for fermentation are 4.5 and $30^{\circ} \mathrm{C}$ respectively.

2) The effect time on fermentation

The optimum duration for the fermentation of the plantain peals was 9 days. The duration of the fermentation had a significant effect on fermentation as can be seen in Table $7(\mathrm{p}<0.005)$. From Figure 10, it can be seen that there was a sharp increase in the percentage yield of ethanol from 5 to 9 days of incubation.

Time had an interactive effect with temperature as can be seen from the curves of the contour plot of Figure 10. This significant interactive effect can also be seen from the ANOVA table of Table 7 . The interactive effect 
Table 8. The optimum numerical solution for fermentation.

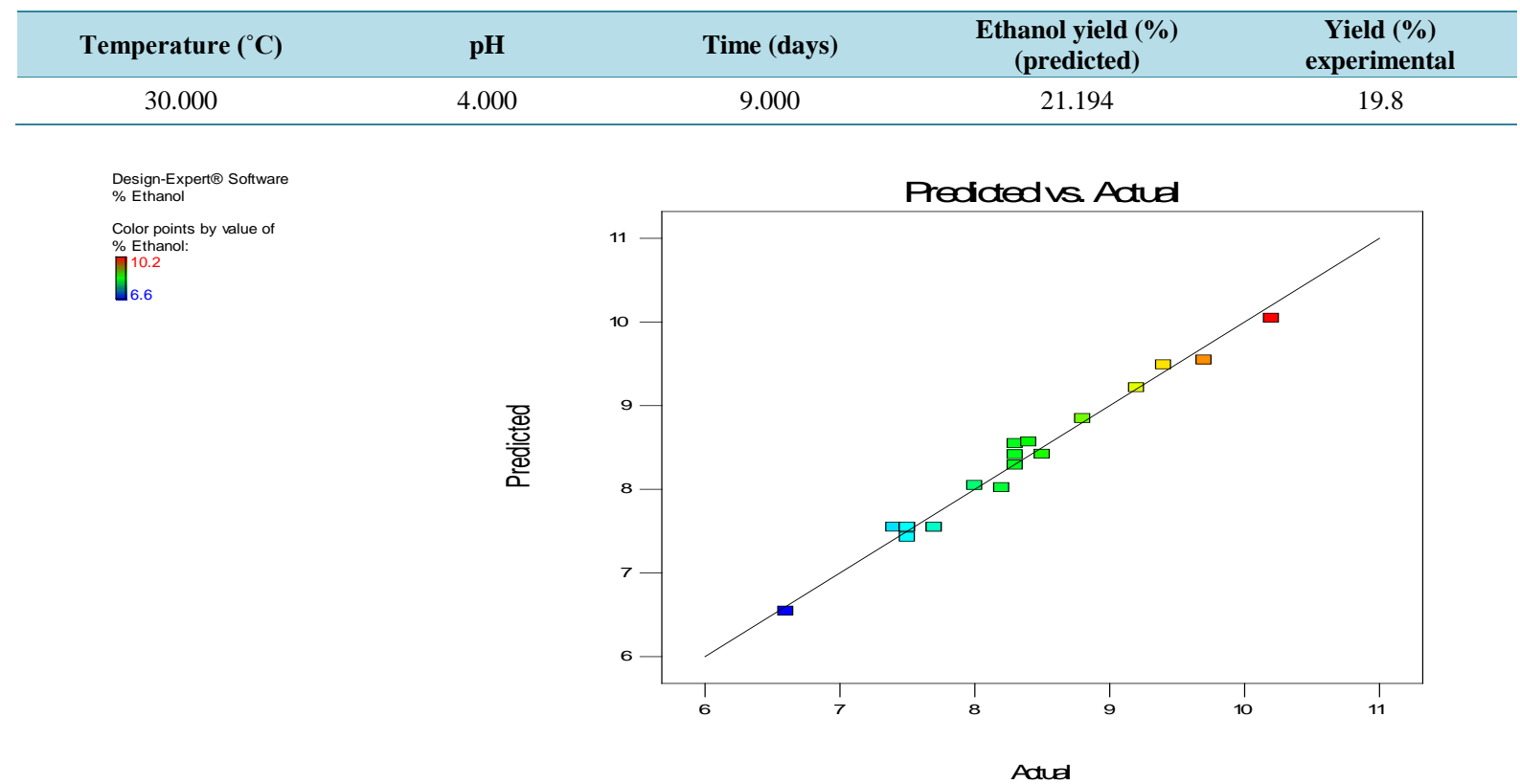

Figure 8. The predicted values against the actual values in optimization of the fermentation process.
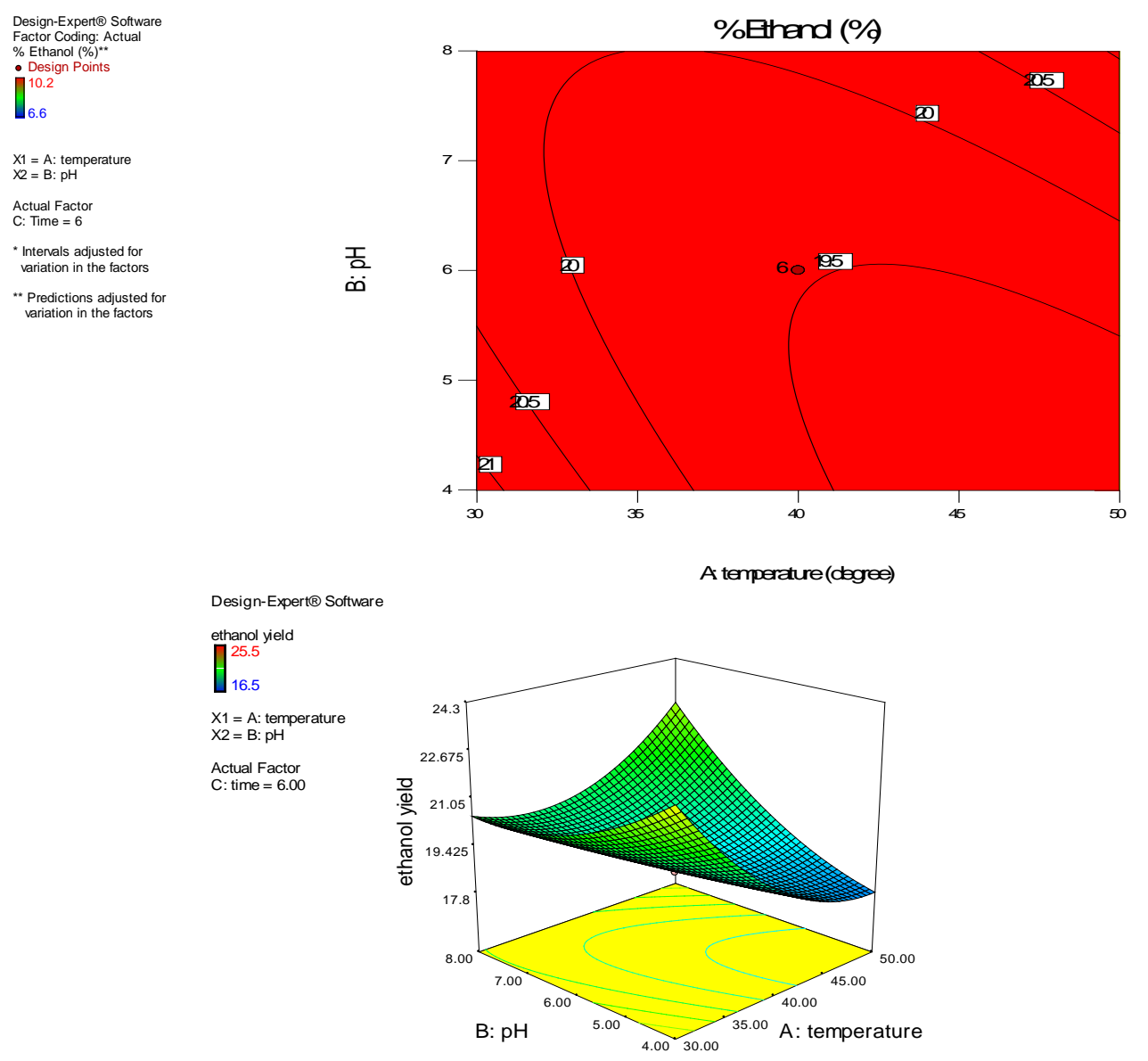

Figure 9. The contour and 3D plots of pH against temperature. 
Design-Expert $\circledast$ Software Factor Coding: Actual $\%$ Ethanol $(\%)^{\star \star}$ - Design Points 10.2

6.6

$X_{1}=A:$ temperature

$\mathrm{X} 2=\mathrm{C}:$ Time

Actual Factor
B: $\mathrm{pH}=6$

* Intervals adjusted for variation in the factors

** Predictions adjusted for variation in the factors

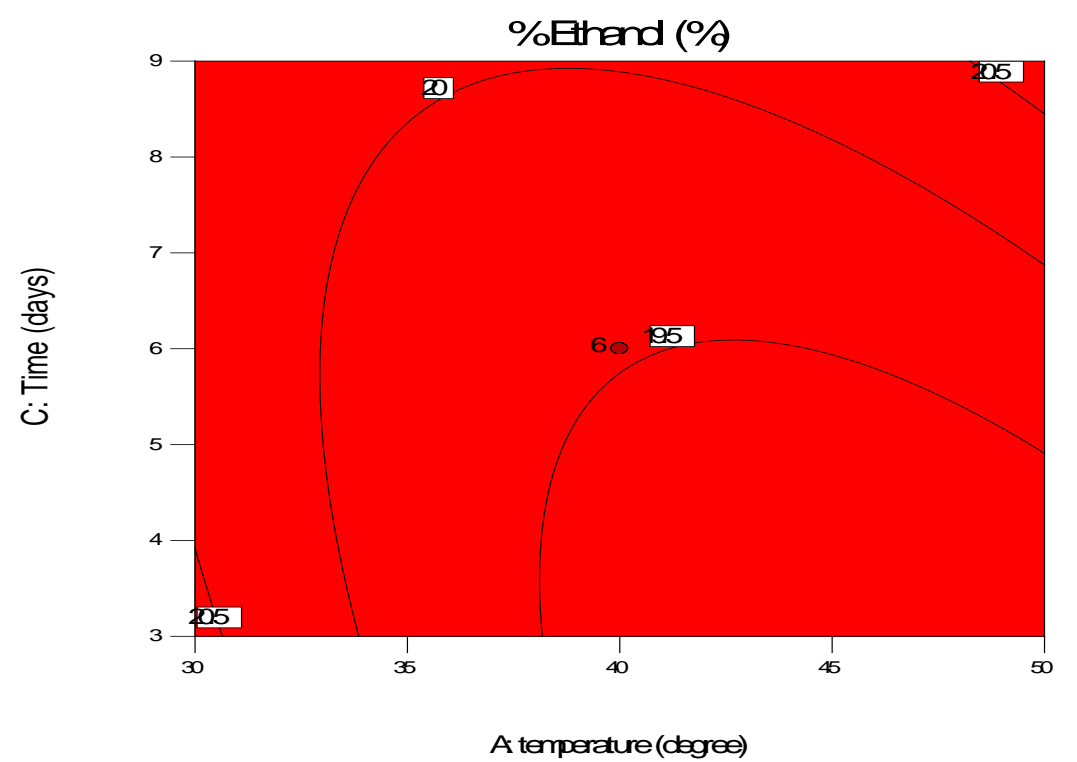

Design-Expert® Software

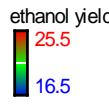

$\mathrm{X} 1=\mathrm{A}:$ temperature $\mathrm{X} 2=\mathrm{C}:$ time

Actual Factor B: $\mathrm{pH}=6.00$

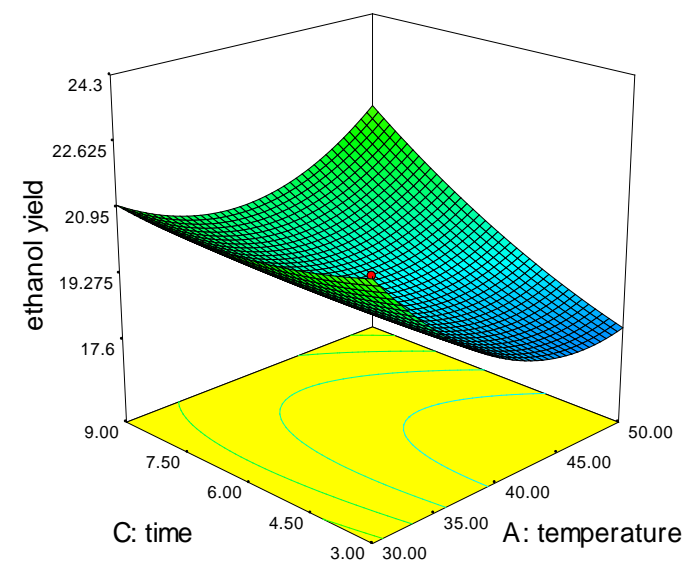

Figure 10. The contour and 3D plots of time against temperature.

of time with $\mathrm{pH}$ is obvious from the contour plot of Figure 11 but the ANOVA table shows that the interaction was not significant.

Akponah and Akpomie [22] recorded an ethanol yield of 17.52\% (v/w) over 72hours of incubation of cassava peels hydrolyzed with Aspergillus niger. Itelima et al. [6] stated that the ethanol yield obtained from plantain peels, cassava peels, and potato peels increases gradually from the first day to the seventh day of incubation with pineapple peels given up to $8.34 \%$ (v/v) yield of ethanol. Bukola et al. [25] reported that biter kola fermented with baker's yeast could yield up to $2.16 \%$ (v/v) ethanol.

3) The effect of temperature on fermentation

The optimum temperature for the fermentation of the hydrolyzed plantain peels was $30^{\circ} \mathrm{C}$. Temperature was a significant factor of fermentation as can been seen from the ANOVA table of Table 7 ( $p<0.005)$. The significant interactive effect of temperature with time and $\mathrm{pH}$ can be seen from the contour plot of Figure 10 and Figure 11 respectively. Also from the ANOVA table of Table 7 the significant interactive effect can be seen.

This optimum fermentation temperature of $30^{\circ} \mathrm{C}$ had been widely reported by other researchers [6] [16] [23] [24]. Highina et al. [23] stated that there is excessive enzyme degradation and loss of cell viability at temperature above $30^{\circ} \mathrm{C}$. 

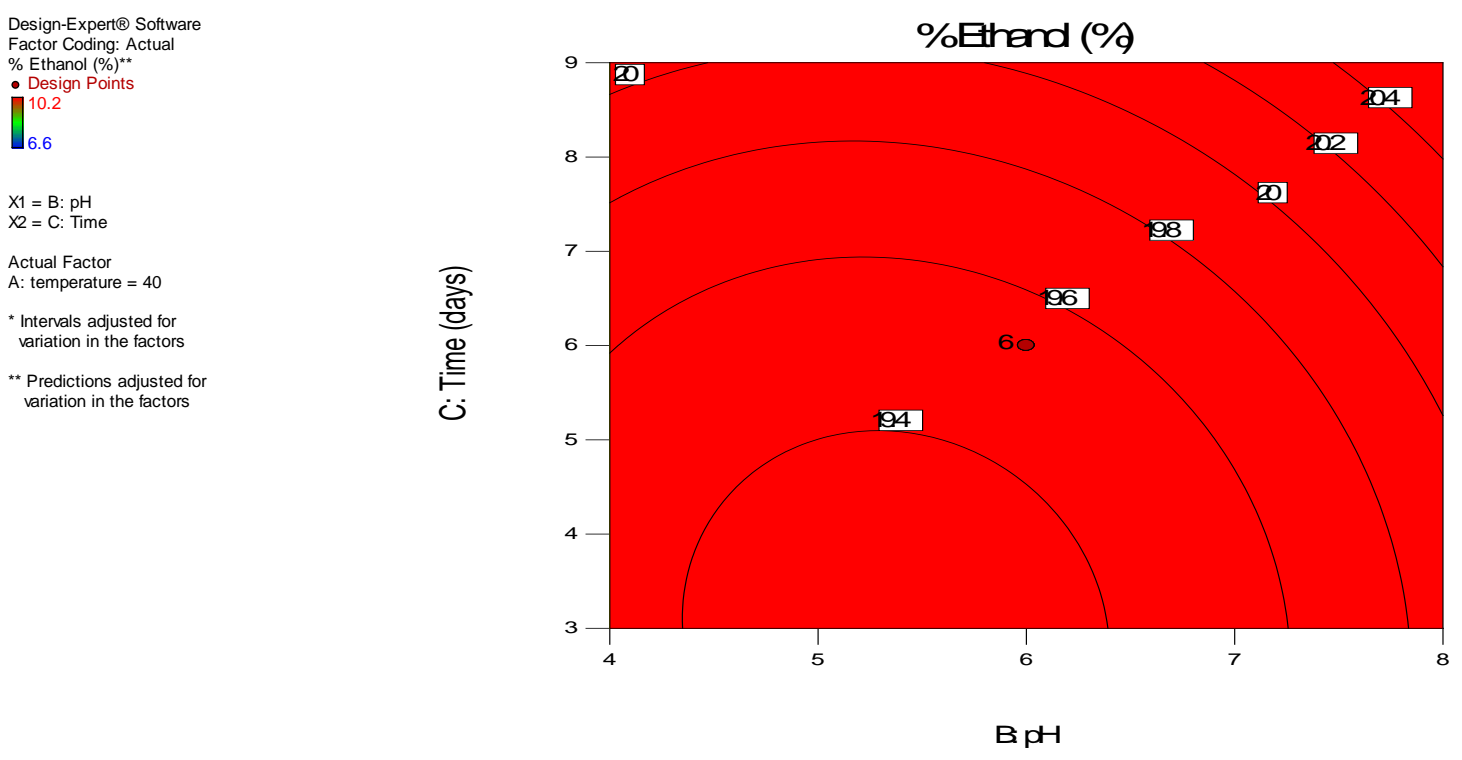

Design-Expert® Software

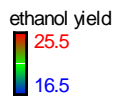

$\mathrm{X} 1=\mathrm{B}: \mathrm{pH}$

$\mathrm{X} 2=\mathrm{C}:$ time

Actual Factor

A: temperature $=40.00$

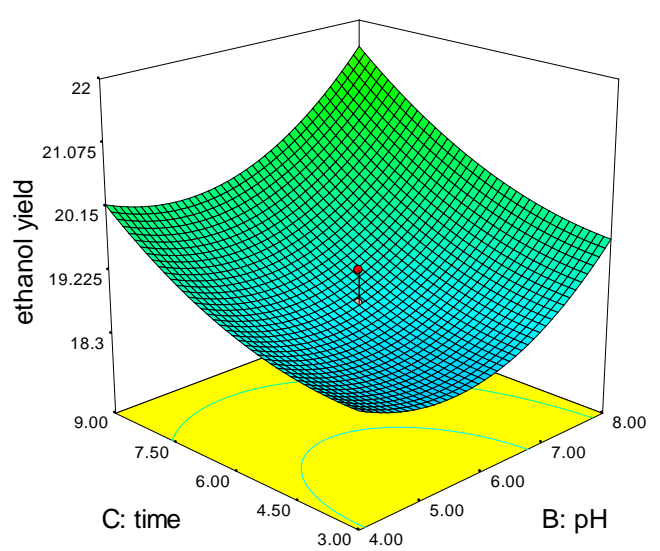

Figure 11. The contour and 3D plots of time against pH.

\subsection{Kinetics of the Enzymatic Hydrolysis}

Table 9 shows the decrease in concentration of cellulose contained in the plantain peels with time at a given concentration of the enzyme. The differential change of the cellulose concentration was calculated using the numerical method [18].

\subsubsection{The Michaelis-Menten Model}

Following the linear form of model equation (Equation (7))

$$
-\frac{1}{r_{\mathrm{A}}}=\frac{1}{V_{\max }}+\frac{K_{m}}{V_{\max }}\left(\frac{1}{C_{A}}\right) .
$$

The kinetics parameters and the fitness were determined using the linear plot shown in Figure 12.

The value of the correlation coefficient $R^{2}$, being close to 1 shows that Michaelis-Menten model described the kinetics of the enzymatic hydrolysis. It can be seen that the rate of the reaction decreased with time and remained almost constant after the fifth day Table 10.

Using the Michaelis-Menten parameters calculated, the kinetics equation for the hydrolysis was obtained as shown in Equation (13) by substituting the parameters into Equation (6). 
Table 9. Change in cellulose concentration with time.

\begin{tabular}{ccccc}
\hline Time (days) & Cellulose conc. $(\mathrm{g} / \mathrm{L})$ & Rate of reaction & $C_{A}^{-1}$ & $-r_{A}^{-1}$ \\
\hline 0 & $C_{A}$ & $-r_{A}$ & 0.02 & 0.053 \\
1 & 49 & 19 & 0.03 & 0.067 \\
2 & 32 & 15 & 0.05 & 0.095 \\
3 & 19 & 10.5 & 0.09 & 0.143 \\
4 & 11 & 7 & 0.2 & 0.2 \\
\hline
\end{tabular}

Table 10. Michaelis-Menten kinetics parameters for hydrolysis.

\begin{tabular}{ccc}
\hline$K_{m}\left(\mathrm{~g} \cdot \mathrm{dm}^{-3}\right)$ & $V_{\max }\left(\mathrm{g} \cdot \mathrm{dm}^{-3} \cdot \mathrm{day}^{-1}\right)$ & $R^{2}$ \\
\hline 16.2 & 20.4 & 0.946 \\
\hline
\end{tabular}

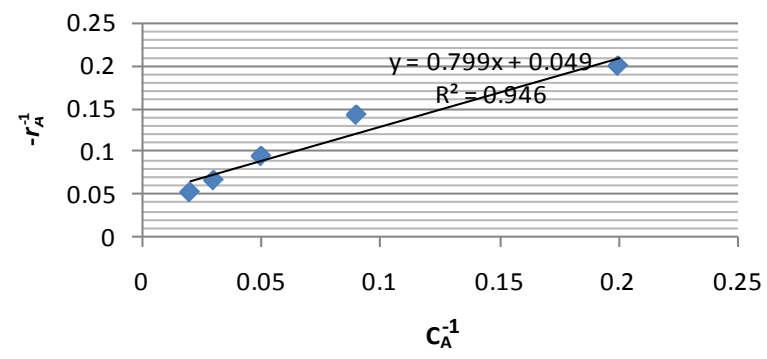

Figure 12. The Michaelis-Menten Kinetic Model for enzymatic hydrolysis of plantain peels.

$$
\begin{aligned}
& -r_{A}=\frac{V_{\max } C_{A}}{K_{m}+C_{A}} \\
& -r_{A}=\frac{20.4 C_{A}}{16.2+C_{A}}
\end{aligned}
$$

\subsection{The Kinetics of the Feremntation}

The kinetics of the fermentation was modeled using the Michaelis-Menten equation. The concentration of the glucose in the fermentation is measured with time using the DNS method. The numerical method is used to calculate the differential change in glucose concentration with time. Table 11 shows the result of the kinetics study while the kinetic parameters were determined using the linear plot in Figure 13.

The closeness of $R^{2}$ to 1 also confirmed that the kinetics of the fermentation was described by the MichaelisMenten equation.

Based on the values of the Michaelis-Menten parameters in Table 12, the kinetics equation for fermentation was given was obtained as shown in Equation (14):

$$
-r_{A}=\frac{28.6 C_{A}}{39+C_{A}}
$$

\section{Conclusion}

The quadratic model of central composite rotatable design CCRD was an adequate model for the enzymatic hydrolysis of plantain peels using Aspergillus niger. Temperature, time, $\mathrm{pH}$ and substrate concentration were significant factors that affected the yield of simple sugar in enzymatic hydrolysis. The optimum parameters in enzymatic hydrolysis were $35^{\circ} \mathrm{C}$, 5 days, 5.5 and $8 \mathrm{~g} / 30 \mathrm{ml}$ for temperature, time, $\mathrm{pH}$ and substrate concentration 
Table 11. Change in glucose concentration with time.

\begin{tabular}{ccccc}
\hline Time (days) & Glucose conc: $C_{A}\left(\mathrm{~g} / \mathrm{dm}^{3}\right)$ & $1 / C_{A}$ & $\begin{array}{c}\text { Rate: }-r_{A} \\
\left(\mathrm{~g} / \mathrm{dm}^{3} / \mathrm{day}\right)\end{array}$ & $-1 / r_{A}$ \\
\hline 0 & 83 & 0.012 & 39.5 & 0.025 \\
1 & 50 & 0.020 & 26.5 & 0.038 \\
2 & 30 & 0.033 & 13.0 & 0.077 \\
3 & 24 & 0.042 & 8.0 & 0.125 \\
4 & 14 & 0.071 & 7.5 & 0.133 \\
6 & 9 & 0.111 & 4.5 & 0.222 \\
\hline
\end{tabular}

Table 12. The Michaelis-Menten parameters for fermentation.

\begin{tabular}{rcc}
\hline$K_{m}\left(\mathrm{~g} \cdot \mathrm{dm}^{-3}\right)$ & $V_{\max }\left(\mathrm{g} \cdot \mathrm{dm}^{-3} \cdot \mathrm{day}^{-1}\right)$ & $R^{2}$ \\
\hline 39 & 28.6 & 0.921 \\
\hline
\end{tabular}

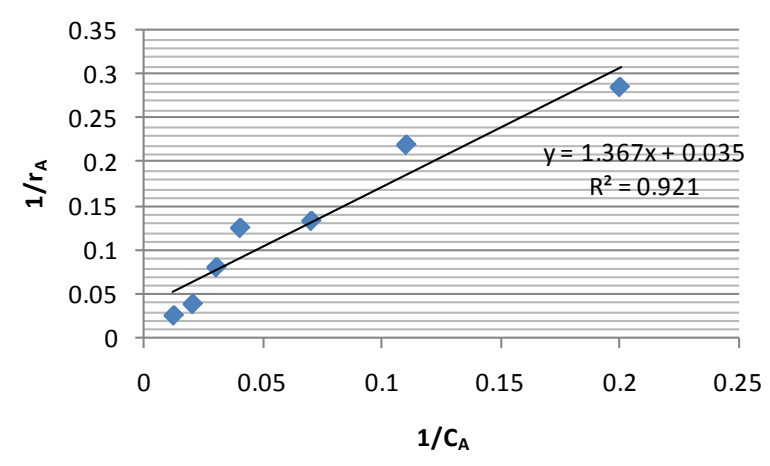

Figure 13. The Michaelis-Menten model for fermentation of hydrolyzed plantain peels.

respectively. The quadratic model of central composite rotatable design was also an adequate model for fermentation of the hydrolyzed peels. The fermentation optimum parameters were $30^{\circ} \mathrm{C}, 9$ days and 4.0 for temperature, time and $\mathrm{pH}$ respectively. It can be concluded that Aspergillus niger can yield 50\% simple sugar from plantain peels and the feremtation using Saccharomyces cerevisae can yield 20\% ethanol when the optimum conditions are observed. The kinetics of the hydrolysis and the fermentation follows the Michaelis-Menten model as can be seen by the correlation coefficient of the model.

\section{References}

[1] Lalitha, G. and Sivaraj, R. (2011) Use of Fruit Biomass Peel for Ethanol Production. International Journal of Pharma and Bio Sciences, 2, 15-23.

[2] SECO 2006: State Secretariat for Economic Affairs. www.seco.admin

[3] Erdei, B., Hancz, D., Galbe, M. and Zacchi, G. (2013) SSF of Steam Pretreated Wheat Straw with the Addition of Saccharified or Fermented Wheat Meal in Integrated Bioethanol Production. Biotechnology for Biofuels, 6, 169. http://dx.doi.org/10.1186/1754-6834-6-169

[4] Akpan, U.G., Alhakim, A.A. and Ijah, U.J.J. (2008) Production of Ethanol from Organic and Food Wastes. Leonardo Electronic Journal of Practices and Technology, 7, 1-11.

[5] Zheng, Y., Pan, Z. and Zhang, R. (2009) Overview of Biomass Pretreatment for Cellulosic Ethanol Production. International Journal of Agricultural and Biological Engineering, 2, 51-68.

[6] Itelima, J., Onwuliri, F., Onwuliri, E., Onyimba, I. and Oforji, S. (2013) Bio-Ethanol Production from Banana, Plantain 
and Pineapple Peels by Simultaneous Saccharification and Fermentation Process. International Journal of Environmental Science and Development, 4, 213-216. http://dx.doi.org/10.7763/IJESD.2013.V4.337

[7] Galbe, M. and Zacchi, G. (2002) A Review of the Production of Ethanol from Softwood. Applied Microbiology and Biotechnology, 59, 618-628. http://dx.doi.org/10.1007/s00253-002-1058-9

[8] Ezeonu, I.M., Okafor, J.I. and Ogbonna, J.C. (2011) Laboratory Exercises in Microbiology. Ephrata Press, Nsukka.

[9] Ighodaro, O.M. (2012) Evaluation Study of Nigerian Species of Musa paradisiaca Peels. http://www.sciencepub.net/researcher

[10] Horwitz, W. and Latima, G. (2005) Official Method of Analysis. Association of Organic and Applied Chemistry (AOAC) International.

[11] Ververis, C., Georghiou, K., Danielidis, D., Hatzinikolaou, D., Santas, P., Santas, R. and Corleti, V. (2007) Cellulose, Hemicelluloses, Lignin and Ash Content of Some Organic Materials and Their Suitability for Use as Paper Pulp Supplements. Bioresource Technology, 98, 296-301. http://dx.doi.org/10.1016/j.biortech.2006.01.007

[12] Kulić, G.J. and Radojičić, V.B. (2011) Analysis of Cellulose Content in Stalks and Leaves of Large Leaf Tobacco. Journal of Agricultural Science, 56, 207-215.

[13] Eneojo, A.S., Aliyu, S. and Bukbuk, D.N. (2010) Potentials of Wild Strains of Saccharomyces cerevisiae in Ethanol Production. American-Eurasian Journal of Scientific Research, 5, 187-191.

[14] Ahmad, F., Jameel, A.T., Kamarudin, M.H. and Mel, M. (2011) Study of Growth Kinetic and Modeling of Ethanol Production by Saccharomyces cerevisiae. African Journal of Biotechnology, 16, 18842-18846.

[15] Kongkiattikajorn, J. (2012) Ethanol Production from Dilute Acid Pretreated Cassava Peel by Fed-Batch Simultaneous Saccharification and Fermentation. International Journal of the Computer, the Internet and Management, 20, 22-27.

[16] Oyeleke, S.B., Dauda, B.E.N., Oyewole, O.A., Okoliegbe, I.N. and Ojobode, T. (2012) Production of Bioethanol from Cassava and Sweet Potato Peels. Advanced in Environmental Biology, 6, 241-245.

[17] Spiegel, M.R. and Stephens, L.J. (2011) Schaums Statistics. McGraw-Hill, New York.

[18] Fogler, H.S. (1999) Elements of Chemical Reaction Engineering. Prentice Hall of India, New Delhi.

[19] Lazic, Z.R. (2004) Design of Experiment in Chemical Engineering. Wiley-VCH Verlag GmbH \& Co. KGaA, Weinheim.

[20] Tengborg, C., Galbe, M. and Zacchi, G. (2001) Influence of Enzyme Loading and Physical Parameters on the Enzymatic Hydrolysis of Steam-Pretreated Softwood. Biotechnology Progress, 17, 110-117. http://dx.doi.org/10.1021/bp000145+

[21] Zakpaa, H.D., Mak-Mensah, E.E. and Johnson, F.S. (2009) Production of Bio-Ethanol from Corncobs Using Aspergillus niger and S. cerevisiae in Simultaneous Saccharification and Fermentation. African Journal of Biotechnology, 8, 3018-3022.

[22] Akponah, E. and Akpomie, O.O. (2011) Analysis of the Suitability of Yam, Potato and Cassava Root Peels for Bioethanol Production Using Saccharomyces cerevisiae. International Research Journal of Microbiology, 2, 393-398.

[23] Highina, B.K., Hashim, I. and Bugaje, I.M. (2011) Optimization of Ethanol Production from Sugar Molasses in Nigeria. Journal of Applied Technology in Environmental Sanitation, 1, 233-237.

[24] Reddy, L.V., Reddy, O.V.S. and Wee, Y.-J. (2011) Production of Ethanol from Mango (Mangifera indica L.) Peel by Saccharomyces cerevisiae CFTRI101. African Journal of Biotechnology, 10, 4183-4189.

[25] Akin-Osanaiye, B.C., Nzelibe, H.C. and Agbaji, A.S. (2006) Preliminary Studies on Ethanol Production from Garcinia kola Pod, Effect of Saccharification and Different Treatment on Ethanol Yield. Biokemistri, 18, 105-109. 